\title{
PERFORMANCE OF A PYRAMID SOLAR STILL USING AIR-COOLED GLASS COVER: AN EXPERIMENTAL STUDY
}

\author{
M. A. Tawfk*
}

\section{ABSTRACT}

Cooling the glass cover is considered one of the most effective modifications that affecting the performance of any solar still, particularly at summer season. Many previous studies focused on the water cooling glass cover, but it is important to study another cooling technique to avoid using potable or saline water in this process. Thus, this study aims to investigate the possibility of enhancing the performance of a passive square pyramid-shaped solar still in summer season through cooling the glass cover using controlled stream of cooled air. For this purpose, the solar still was coupled to ice-cooling unit provided with a high pressure fan in trial to reduce the temperature of the blowing ambient air over the glass cover. Solar still performance was evaluated using saline water (15000ppm) depth of 4cm without cooling as a control treatment and air-cooled glass cover under different values of air velocities and cooling tactics with taking into consideration the solar still temperatures, productivity and instantaneous efficiency. The obtained results revealed that, the increase of the cooled air velocity from $1.4 \mathrm{~m} / \mathrm{s}$ (natural wind) to $5 \mathrm{~m} / \mathrm{s}$ and cooling tactic of $20_{\min }$ on $-10_{\min }$ off gave a remarkable increase in water-inner glass temperature difference $\left(\Delta T_{w g i}\right)$ from 10 to $21^{\circ} \mathrm{C}$ and the productivity from 0.505 to $0.645 \mathrm{~L} / \mathrm{m}^{2} . h$ at the peak performance hour which led to achieve the highest accumulated yield of $3.545 \mathrm{~L} / \mathrm{m}^{2}$.day and instantaneous efficiency of $43.2 \%$ with an increment of about 17 and 10.8\%, respectively higher than solar still without cooling. Additionally, the air velocity of $7 \mathrm{~m} / \mathrm{s}$ has irrelevant effect on the solar still performance, but on the contrary it gave less improvement. Hence, it is obvious that the air-cooled glass cover enhanced the solar still performance.

Keywords: pyramid-shaped solar still, cooling, glass cover, air velocities, cooling tactics, solar still performance

\footnotetext{
*Assistant. Prof., Agric. Eng. Dept., Fac. of Agric., Zagazig Univ., Egypt.
} 


\section{INTRODUCTION}

The reduction of potable water sources availability and contamination resulting in a high shortage in the pure drinking

1 water quantity all over the world and this problem will be aggravated with the rapid increase of population and the human activities against the environment. Moreover, the expensive transportation is a tough barrier to provide the communities in desert, remote and isolated regions with adequate fresh water. Solar still is considered a simple rout to produce potable water from saline water with relatively low cost in structure, operation and maintenance (Velmurugan and Srithar, 2011). Solar still can provide the mentioned regions with potable water in small scale, where the solar energy and saline water are abundantly, or if there is no other sources of energy (Tiwari et al., 2003). In the same time, the major disadvantage of solar still is the low productivity of the distilled water and can't compete with the other desalination systems (Nafey et al., 2002), noting that the maximum efficiency of the conventional solar still is being around 50\% (Kaushal, 2010). So, the daily productivity of solar still is required to be enhanced continuously. The main factors affecting the productivity of solar still are the solar radiation intensity, wind speed, ambient temperature, water-glass cover temperature difference, free surface area of saline water, absorber basin area, inlet water temperature, glass cover angle, brine depth (Nafey et al., 2000; Samee et al.,2007). Furthermore, various modifications to enhance the solar still productivity and efficiency such as; using internal and external reflectors (Tanaka and Nakatake, 2006), black rubber (Nafey et al., 2001), black stones (Tawfik, 2012) and wicked evaporation surface (Kabeel, 2009). One of the most effective modifications to improve the solar still productivity is cooling the glass cover (Kalidasa et al., 2008). The rate of condensation can be improved by decreasing the temperature of glass cover the glass cover temperature can be decreased by cooling using water, air, or combination between them by using the flowing water air on the glass cover (Suneesh et al., 2014). The most of cooling process techniques were performed using hoses, but the water sprinkler (Tarawneh, 2007) also investigated. Somwanshi and Tiwari (2014) addressed the effect of water film above the glass cover of single slope still using water at 
ambient temperature and the cold water introduced by the evaporative cooler. They concluded that the cold water increased the annual productivity by about 41.3 to $56.5 \%$ and the water at ambient temperature from 21.8 to 30.1.On one hand, some literatures indicated that, the cooling glass cover of different solar still designs enhances the daily productivity up to $11.82 \%$ for double slope still (Zeroual $\boldsymbol{e t}$ al., 2011); 8.2\% for stepped still (El-Samadony and Kabeel, 2014); $32.8 \%$ for triple solar still integrated with parabolic concentrator (Sirthar et al., 2016).On the other hand, the improper water flow rate and still design leads to diminished the incident solar radiation on the still (Omara et al., 2017) and consequently the productivity and thermal efficiency of still will be declined. This is considered as a major disadvantage of water cooling technique, in addition to wasting a portion of potable water in the cooling process that makes the still performance is not effectively. Generally, limited attempts were executed to investigate the influence of flowing air on the glass cover on the performance of solar still. Al-Garni (2012) used an external fan for cooling the glass cover of double slope solar still by the flowing air in winter season. He concluded that the external fan gave more productivity with lower depths of brine not exceed $1 \mathrm{~cm}$, whereas the productivity declined by about 4 and $8 \%$ by increasing the wind speed to 7 and $9 \mathrm{~m} / \mathrm{s}$, respectively. El-Sebaii (2004) summarized that, the single effect passive solar still has a critical brine depth which beyond the distilled water productivity increases as wind velocity increases. The numerical calculations indicated that the depths below the critical depth leads to decrease the productivity by increasing the wind velocity until typical velocity $(10$ and $8 \mathrm{~m} / \mathrm{s}$ for the summer and winter seasons, respectively). The critical depth of basin water for the investigated single effect passive stills was found to be $4.5 \mathrm{~cm}$. Hence, most of previous studies are focused on simulating and numerical calculations for the effect of wind speed on the still performance. Regarding this work, there is no previous literatures about practical trials for cooling the glass cover of solar still by a controlled or regulated stream of air. As the pyramidshaped solar still has large condensation area (Taamneh and Taamneh, 2012), so this design of solar can help to maximize the distilled water productivity (Bhardwaj et al., 2015). Nayi and Modi (2017) indicated 
that, the pyramid solar still doesn't require orientation or tracking mechanism, cheap, simple in structure, large condensation area, high productivity, no shadowing on the basin brine. The efficiency of this type of solar stills can reach about 50\% (Wasouf et al., 2011). Practically, the glass cover sheets with small inclination angle that corresponding to the latitude of experimental site $\left(30.5^{\circ}\right)$ has small enclosure in addition to the small condensation area. Therefore, the present paper aims to investigate the possibility of enhancing the productivity and thermal efficiency of a passive square pyramid-shaped solar still that has relatively high glass inclination angle (up to $45^{\circ}$ ) through cooling the glass cover using controlled stream of cooled air to make difference between the inner and outer surface of the glass cover to increase the condensation rate under the Egyptian climatic conditions.

\section{MATERIALS AND METHODS}

The practical experiments were performed at Zagazig City, Egypt (Lat. $30^{\circ} 35 \% N$, Long. $31^{\circ} 31^{\searrow}$ E) during September, 2017. In the present work, the performance of a square pyramid-shape solar still was using one of the most effective modifications that represents in cooling effect on glass cover by regulated cooled-air stream.

\section{The experimental setup}

\subsection{The saline water}

The saline water used in this study was brackish water (15000 ppm).

\subsection{The experimental solar desalination system}

The experimental solar desalination system is mainly consists of a solar still unit integrated with cooling unit, as shown in Fig.(1). The components of desalination system can be described as follows:

\subsubsection{Solar still unit}

The solar still unit consists of a passive square pyramid-shape solar still and the saline water tank. The still was fabricated in local workshop at Zagazig city, Egypt. The solar still has a square basin that made of galvanized iron sheet with $0.15 \mathrm{~cm}$ in thickness. The basin was constructed with square area of $0.64 \mathrm{~m}^{2}(80 \times 80 \mathrm{~cm})$ and $7 \mathrm{~cm}$ in depth which painted from inside with a synthetic black matt paint. The bottom and the side -walls of the basin were coated from outside with $10 \mathrm{~cm}$ of glass wool layer as heat insulator to prevent the heat leakage to ambient. 
The basin was contained in a square wooden box with inner dimensions of $100 \times 100 \times 17 \mathrm{~cm}$, and $0.03 \mathrm{~m}$ in thickness.

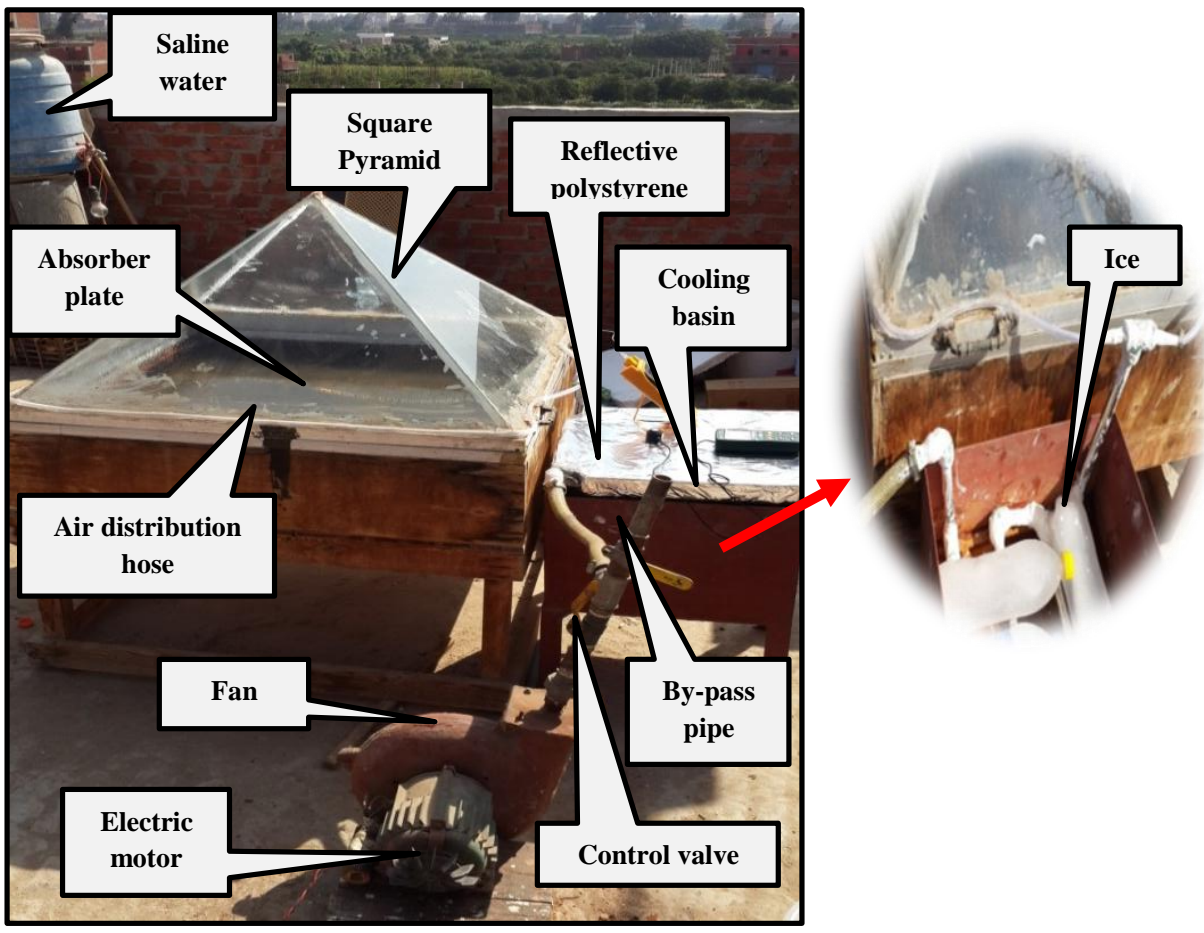

Fig.(1): The experimental solar desalination system.

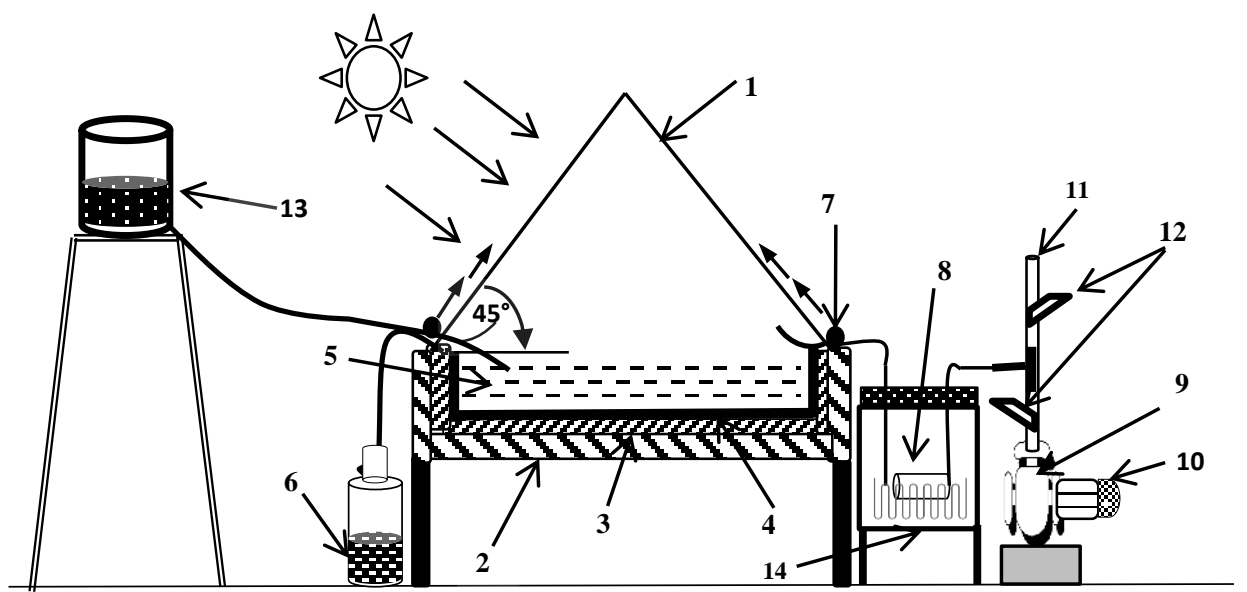

Fig.(2): Schematic diagram of the modified solar desalination system

1-Pyramid solar still, 2-Wooden box, 3-Glass wool, 4-Saline water basin, 5-Saline water, 6-Graduated bottle, 7- Air distribution hose with vents, 8- Ice, 9-high pressure fan,10-Electric motor, 11-By-pass pipe, 12-Control valves, 13-Saline water tank, 14-Cooling basin 
The wooden container was putted on four poles at height of $60 \mathrm{~cm}$ above the ground. The solar still was covered with four triangle clear panels of commercial glass with surface area of $0.187 \mathrm{~m}^{2}$ (93.5 Base $\times 40$ Height $\mathrm{cm}$ )for each panel and total area $0.75 \mathrm{~m}^{2}$ at inclination angle of $45^{\circ}$ on horizontal and $0.3 \mathrm{~cm}$ in thickness, as shown Fig(2) the pyramid shape cover without frame was created by gathering the glass sheets using silicon rubber sealant. The pyramid glass cover was provided from inside with inclined $U$ shaped troughs to collect the distilled water. A rubber gasket was kept between the glass cover and the wooden container to maintain the heat within the still. Two plastic bottles were connected to the trough by hoses for collecting the still productivity. A $30 \mathrm{~L}$ in capacity plastic tank was used to feed the still with the saline water by hose providing with controlling valve. The feeding mechanism depends on the syphonic effect due to placing the tank at $100 \mathrm{~cm}$ above the basin level.

\subsubsection{The cooling unit}

This unit includes the basin filled with ice bottles (replaced frequently), aluminum serpentine, air distribution hose as well as centrifugal fan. This system has basin made of iron sheet that painted from inside and outside by using anti-corrosion material with overall dimensions of $42 \mathrm{~L} \times 42 \mathrm{~W} \times 40 \mathrm{D} \mathrm{cm}$ and covered by $10 \mathrm{~cm}$ in thickness polystyrene panel provided with reflective film, as shown Fig.(1). An aluminum serpentine works as heat exchanger during passing the blowing air through it to transfer the heat of air to ice bottles. This serpentine has many tubes with an internal diameter of $1.200 \mathrm{~cm}$ and external diameter of $1.270 \mathrm{~cm}(1 / 2$ inch). The serpentine tubes were separated by $14 \mathrm{~cm}$ apart to increase the length of air path as possible. The tubes were fixed on a frame at height of $20 \mathrm{~cm}$ from the bottom of basin. Two vertical tubes with same mentioned dimensions, the input tube which connected with air fan by flexible plastic hose and the other is the output tube that connected to a plastic Tshape joint for air distribution. Air was supplied to the serpentine and then the distribution hose by high pressure centrifugal fan (Model: SAVT, $220 \mathrm{~V}$ ) with nominal speed $3000 \mathrm{rpm}$, motor power of $0.735 \mathrm{~kW}(1 \mathrm{hp})$, maximum air volume $660 \mathrm{~m}^{3} / \mathrm{h}$. The fan was provided with air regulator pipe (by-pass) to control the supplied air velocity, as displayed in Fig (2). The distribution hose is made from plastic with $0.635 \mathrm{~cm}$ provided with 
vents $(0.5 \mathrm{~cm}$ in diameter) and placed at $10 \mathrm{~cm}$ apart. The distribution hose was fixed around the lower edge of glass cover using bonding material (silicon) to secure a continuous stream of air over every face of the glass cover. The hose connected to the T-shaped joint by tapered tube $(1.27 / 0.635 \mathrm{~cm})$

\section{2- Methods}

\subsection{The experimental procedures}

All practical experiments were carried out during the period which started from 9 am to $5 \mathrm{pm}$. Moreover; all readings of temperatures, solar radiation intensity and the fresh water production were recorded every hour in ml. Performance of the passive pyramid solar still without cooling (control treatment) and with air cooling glass cover was studied under at saline water depth of $4 \mathrm{~cm}$. For the air cooling tests, the solar still was evaluated under the following variables:

1- Three levels of air velocity over glass cover $(2.5,5$ and $7.5 \mathrm{~m} / \mathrm{s})$.

2- Three different exposure intervals times of $5 \min$ on $-10_{\min }$ off $\left(\mathrm{Tc}_{1}\right)$, $10_{\min }$ on- $10_{\min }$ off $\left(\mathrm{Tac}_{2}\right)$ and $20_{\min }$ on $-10_{\min }$ off $\left(\mathrm{Tac}_{3}\right)$.

\subsection{Measuring and Determinations}

\subsubsection{Temperature and solar radiation intensity}

As displayed in Fig.(3-a), the temperatures of the ambient, supplied cooled air, saline water, inner and the outer glass cover was measured using K-type thermocouple sensors were plugged to the multi-channels digital data logging thermometer (Model: TM747 DU 4-Channel, Taiwan) with resolution of $0.1^{\circ} \mathrm{C}$, Whereas, the solar radiation intensity was measured using solarimeter (TES-132,TENMARS, Taiwan), with measuring range of $0-2000 \mathrm{~W} / \mathrm{m}^{2}$, resolution $0.1 \mathrm{~W} / \mathrm{m}^{2}$ and accuracy \pm 10 $\mathrm{W} / \mathrm{m}^{2}$. The velocity of air over the glass cover that corresponding a certain openings of the by-pass pipe valve as well as the natural wind were measured using a probe anemometer (TM-4001/4002 Hot WireTENMARS, Taiwan) in range of 0.01 to $25.00 \mathrm{~m} / \mathrm{s}$, resolution $0.01 \mathrm{~m} / \mathrm{s}$ and accuracy $\pm(3 \%$ of reading+1.6\% FS), as depicted in Fig(3-b). 2.2.3. 2.2.2. The solar still productivity and instantaneous efficiency ( $\eta i)$

The passive pyramid solar still productivity was conducted by weighting the collected fresh water in the bottles every hour and consequently the accumulated productivity can be estimated. 

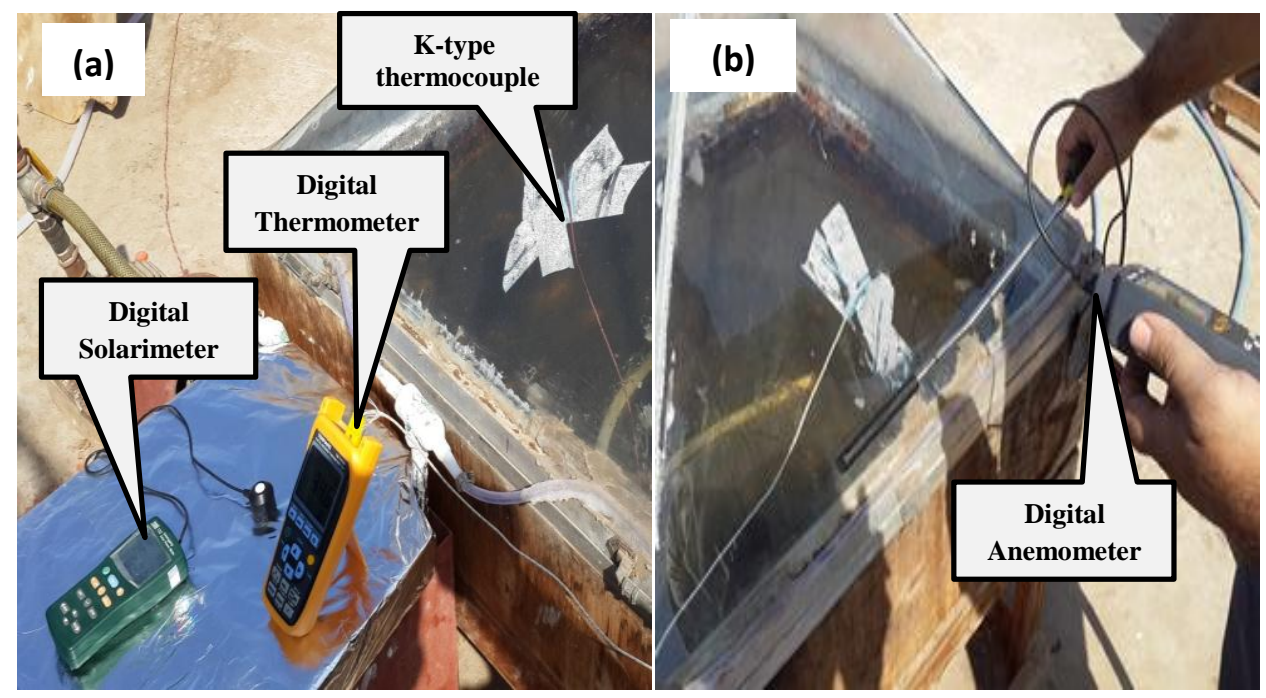

Fig. (3) Instrumentations a) digital thermometer and solarimeter; b) measuring the air velocity over glass cover.

The instantaneous efficiency is an indicator to the amount of the exploited solar energy by the solar cooker. The instantaneous thermal efficiency $\left(\eta_{i}\right)$ can be calculated every hour using the relation given by (Duffie and Beckman, 1991) as follows:

$$
\eta_{i}=\frac{m_{D} h_{f g}}{A g G} \times 100, \%
$$

Where:

$m_{D}=$ production rate of the solar still, $\mathrm{Kg} / \mathrm{h}$

$h_{f g}=$ water latent heat of evaporation, $(2260 \mathrm{~kJ} / \mathrm{kg})$

$G=$ solar radiation flux, $\mathrm{kJ} / \mathrm{m}^{2} . \mathrm{h}$

$A_{g}=$ the glass collecting area, $\mathrm{m}^{2}$

\section{RESULT AND DISCUSSION}

1- Effect of the cooled air velocity and cooling tactics on solar still temperatures

In the present study, the performance of a pyramid shaped solar still was investigated with and without air cooling glass cover under average natural wind speed of $1.4 \mathrm{~m} / \mathrm{s}$ throughout the experimental period that 
extended from $31 / 8$ to $9 / 9 / 2017$. The variation of the solar still temperatures including the ambient air $\left(\mathrm{T}_{\mathrm{a}}\right)$, saline water $\left(\mathrm{T}_{\mathrm{w}}\right)$, inner $\left(\mathrm{T}_{\mathrm{gi}}\right)$, outer $\left(\mathrm{T}_{\mathrm{go}}\right)$ surface of the glass cover and consequently the water - inner glass difference $\left(\Delta \mathrm{T}_{\mathrm{wgi}}\right)$ as well as the solar radiation intensity (SRD) are plotted against time of day in Fig.(4).Regarding to air cooling glass cover, the outer surface of the cover subjected to regulated cooled air stream with average temperature of $28^{\circ} \mathrm{C}$ using different tactics involving certain exposure times and intervals of $5 \mathrm{~m}$ in $\mathrm{On}-10_{\min }$ off $\left(\mathrm{Tac}_{1}\right), 10_{\min }$ on $-10_{\min }$ off $\left(\mathrm{Tac}_{2}\right)$ and $20_{\min }$ on $-10_{\min }$ off $\left(\mathrm{Tac}_{3}\right)$. As a general trend in all experimental days, the hourly solar radiation intensity during the forenoon hours increased rapidly till it reaches the maximum value at noon hour, then it tends to decrease gradually until the sunset hours, whereas the saline water temperature in still basin reached its peak value after the noon hour, then it takes the same trend of SRD distribution during afternoon period. The obtained results showed that, the maximum temperature of saline water decreased slightly by increasing the air velocity from $1.4 \mathrm{~m} / \mathrm{s}$ (natural wind) to $5 \mathrm{~m} / \mathrm{s}$ (cooled air) over the glass cover using $20_{\min }$ on $-10_{\min }$ off as cooling tactic combined with an apparent increase for the saline water-inner glass temperature difference $\left(\Delta \mathrm{T}_{\mathrm{wgi}}\right)$ around noon. But further increase in cooled air velocity up to 7 and under all cooling tactics the $\mathrm{T}_{\mathrm{w}}$ and $\Delta \mathrm{T}_{\mathrm{wgi}}$ will be diminished. Fig.(4) illustrated that, increasing the air velocity from 1.4 to $5 \mathrm{~m} / \mathrm{s}$ (cooled air) and cooling tactic of $20_{\min }$ on $-10_{\min }$ off caused a reduction in $\mathrm{T}_{\mathrm{w}}$ from 71 to $67^{\circ} \mathrm{C}$ followed by a clear increase in $\Delta \mathrm{T}_{\text {wgi }}$ from 10 to $21^{\circ} \mathrm{C}$ at the performance peak hour of $1 \mathrm{pm}$.

Simultaneously, the inner and outer surfaces of glass cover temperatures are taking the same trend of the $\mathrm{T}_{\mathrm{w}}$. It was found that, the $\Delta \mathrm{T}_{\mathrm{wgi}}$ is still relatively low during the morning using the cooling tactics comparing to the still without cooling due to the heat of convection, radiation and evaporation as well as the solar radiation intensity are still low in this period, as depicted in Fig.(4). Concerning to the air velocity of $7 \mathrm{~m} / \mathrm{s}$, the data showed that the $T_{w}$ decreased under all tactics around noon to reach the lowest value of $63^{\circ} \mathrm{C}$ with a moderate values for $\Delta \mathrm{T}_{\text {wgi }}$ and a remarkable decrease at before and after noon time. 


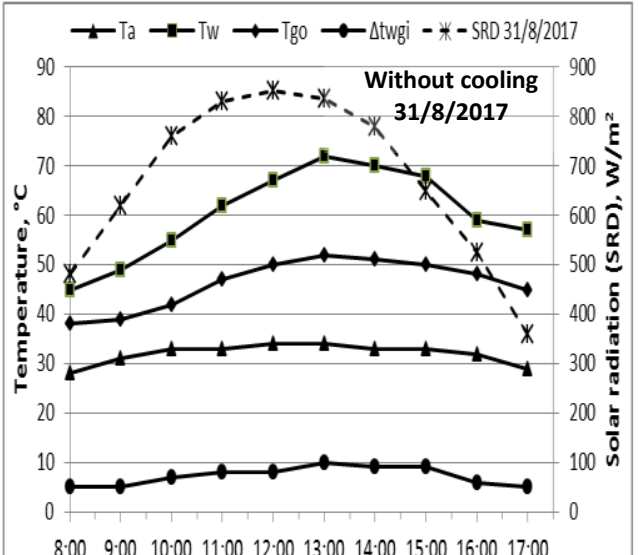

8:00 9:00 10:00 11:00 12:00 13:00 14:00 15:00 16:00 17:00
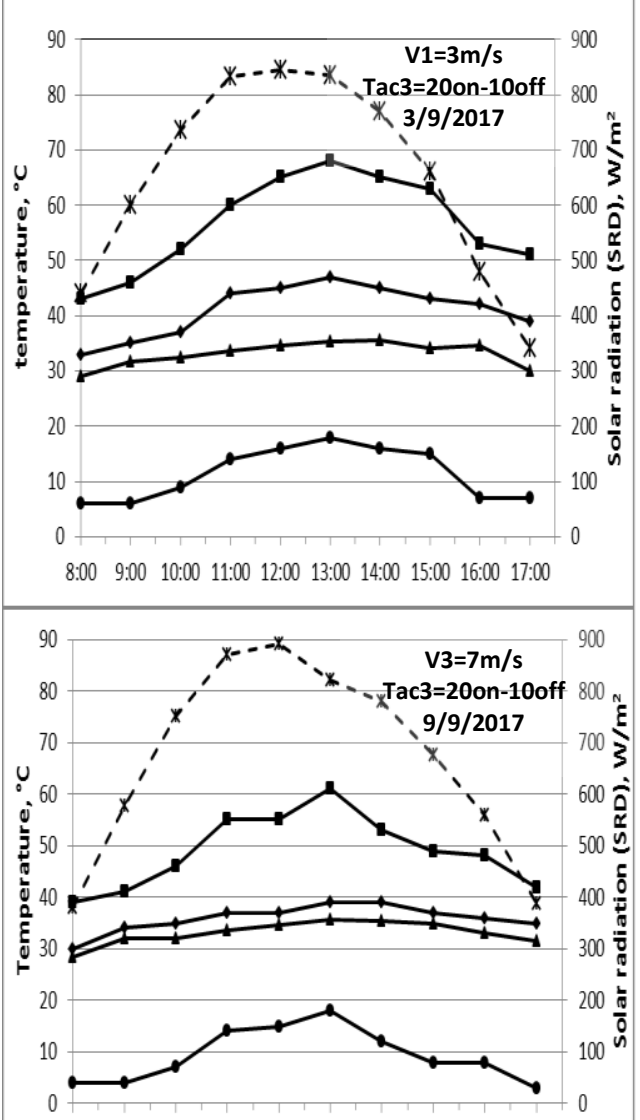

$\begin{array}{lllllllllll}8: 00 & 9: 00 & 10: 00 & 11: 00 & 12: 00 & 13: 00 & 14: 00 & 15: 00 & 16: 00 & 17: 00\end{array}$ Time of day, $\mathrm{h}$

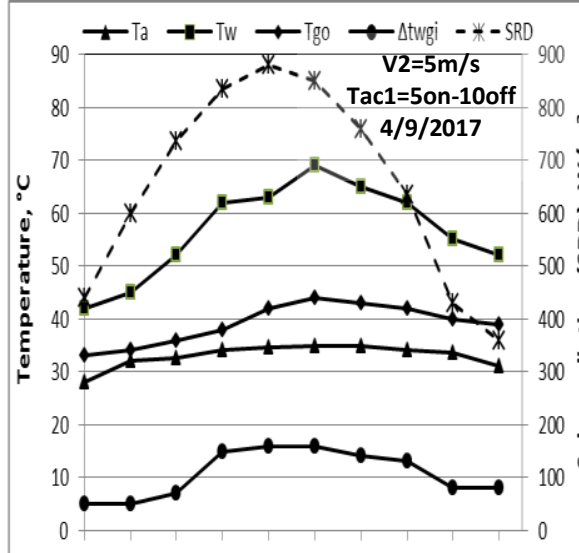

8:00 9:00 10:00 11:00 12:00 13:00 14:00 15:00 16:00 17:00

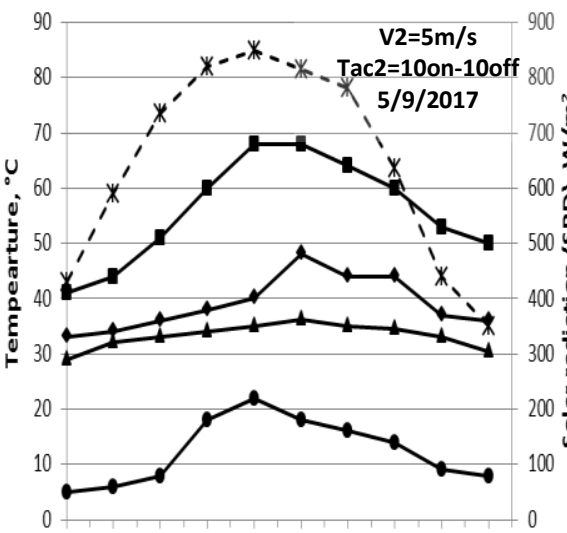

8:00 9:00 10:00 11:00 12:00 13:00 14:00 15:00 16:00 17:00

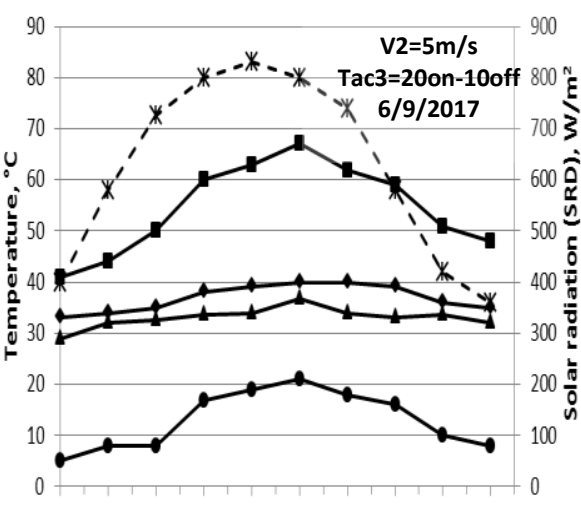

8:00 9:00 10:00 11:00 12:00 13:00 14:00 15:00 16:00 17:00 Time of day, $\mathrm{h}$

Fig. (4): Effect of air velocity and cooling tactic on the solar still temperatures. 
It is obvious that the air velocity up to $5 \mathrm{~m} / \mathrm{s}$ and more exposure time and interval will lead to encourage the increase of evaporation heat flux within the still but at $7 \mathrm{~m} / \mathrm{s}$ this process increased slightly particularly around noon only and this then the still thermal performance will be retarded. As results, the air velocity of $5 \mathrm{~m} / \mathrm{s}$ and cooling tactic $\mathrm{Tac}_{2}$ ( $20_{\min }$ on $-10_{\min }$ off) gave a considerable saline water temperature and the highest saline water -inner glass temperature difference.

\section{2-Effect of the cooled air velocity and cooling tactics on productivity and accumulated yield of the solar still}

The glass cover with no excessive cooling process is playing a vital role for enhancing the condensation rate and consequently the solar still productivity by offering a high temperature difference between the saline water and glass cover throughout the daylight. So, the effect of air velocity and cooling tactics on productivity and accumulated yield of the solar still is shown in Fig. (5). As general trend, the hourly distillate output of the solar still increased rapidly from zero at the beginning of the experimental day to its peak value at $1 \mathrm{pm}$, then it tends to decrease especially under the cooling process due to the reduction in the heat retention within the still, which causes also slow down the increase of accumulated yield at afternoon period. Regarding the highest hourly productivity, data showed that the increase of air velocity from $1.4 \mathrm{~m} / \mathrm{s}$ to 3 and $5 \mathrm{~m} / \mathrm{s}$ (cooled air) at cooling tactic of $20_{\min }$ On $-10_{\min }$ off as cooling tactic the highest hourly distillate at noon increased from 0.505 to 0595 and $0.645 \mathrm{~L} / \mathrm{m}^{2} . \mathrm{h}$ with an increment of about 15.12 and $21.7 \%$, respectively, while this value was $0.615 \mathrm{~L} / \mathrm{m}^{2}$.h at air velocity of $7 \mathrm{~m} / \mathrm{s}$ under the same tactic. It is clear that the increase of cooled air velocity up to $7 \mathrm{~m} / \mathrm{s}$ gave a close or may be lower values of productivity around noon only but remarkable decrease in other periods of day which may reduce the accumulated yield under all cooling tactics comparing to lower air velocities. It is obvious that the effect of cooling process to enhance the productivity was ceased at air velocity of $7 \mathrm{~m} / \mathrm{s}$ and it becomes irrelevant. As an explanation, saline water has a high heat capacity comparing to the glass cover, but the high cooled air velocity with more exposing time will slightly reduce the saline water temperature and glass. 


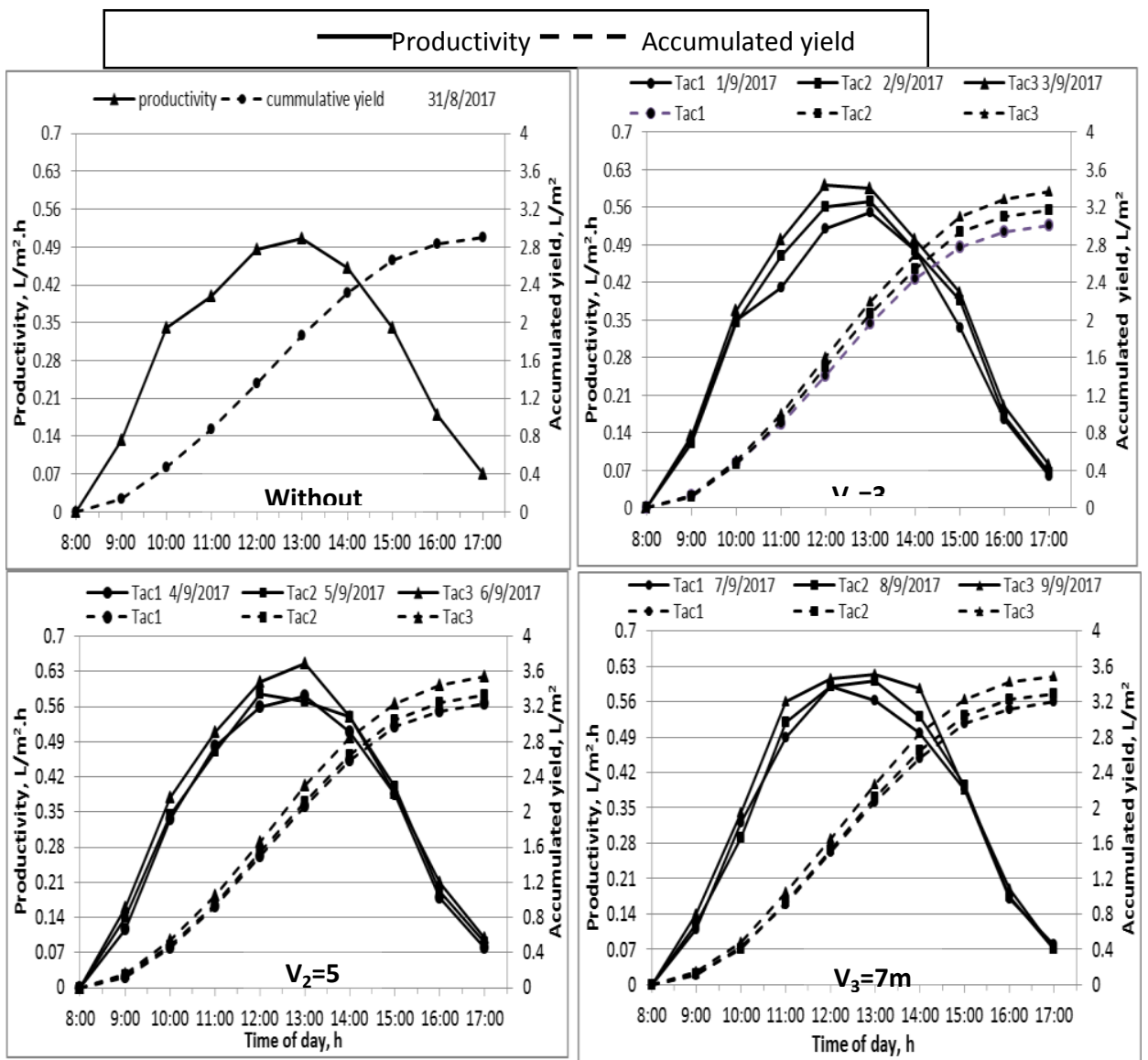

Fig.(5):Effect of air velocity and cooling tactic on the solar still productivity and accumulated yield

With regard to the best accumulated yield, the increase of air velocity from $1.4 \mathrm{~m} / \mathrm{s}$ (without cooling) to $5 \mathrm{~m} / \mathrm{s}$ (cooled air) would increase the accumulated yield from 2.905 to $3.247,3.332$ and $3.501 \mathrm{~L} / \mathrm{m}^{2}$.day at cooling tactics of $55_{\min }$ on $-10_{\min }$ off, $10_{\min }$ On $-10_{\min }$ off and $20_{\min }$ on $10_{\min }$ off, respectively. Nevertheless, the accumulated yield was decreased by increasing the velocity up to $7 \mathrm{~m} / \mathrm{s}$ to $3.21,3.29$ and $3.490 \mathrm{~L} / \mathrm{m}^{2}$.day at the same tactic respectively, as displayed in Fig.(5).The obtained results indicated that the highest accumulated yield of $3.545 \mathrm{~L} / \mathrm{m}^{2}$.day was achieved using the cooled air velocity of $5 \mathrm{~m} / \mathrm{s}$ and cooling tactic $20_{\min }$ on $-10_{\min }$ off $\left(\mathrm{Tac}_{3}\right)$ with an increment of about $17 \%$ higher than solar still without cooling, whereas the air velocity of $7 \mathrm{~m} / \mathrm{s}$ did not improve the solar still productivity. 
3- Effect of air velocity and cooling tactics on the solar still instantaneous efficiency $(\eta i)$

Since the solar still instantaneous efficiency mainly depends on the hourly distillate output, solar radiation intensity and glass condensation area, hence preventing of the heat losses from glass to ambient air by the glass cover cooling will definitely increase the condensation rate which is play an important role for increasing the distillate output and subsequently the solar still thermal instantaneous efficiency will improve. Effect of air velocity and cooling tactics on the solar still instantaneous efficiency is illustrated graphically in Fig. (6).

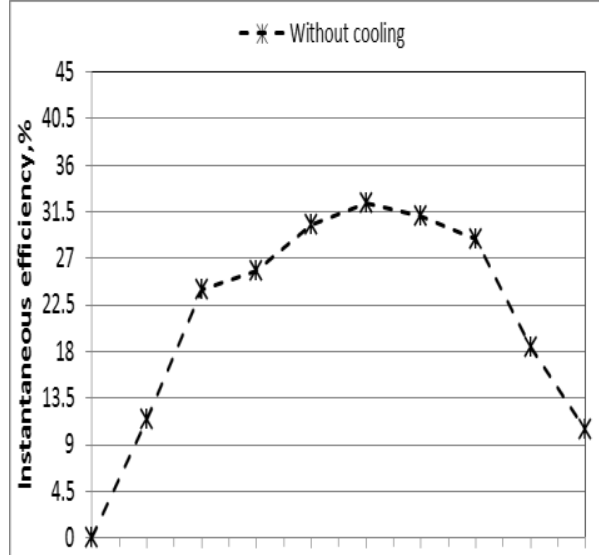

$\begin{array}{lllllllllllllllll}8: 00 & 9: 00 & 10: 00 & 11: 00 & 12: 00 & 13: 00 & 14: 00 & 15: 00 & 16: 00 & 17: 00\end{array}$

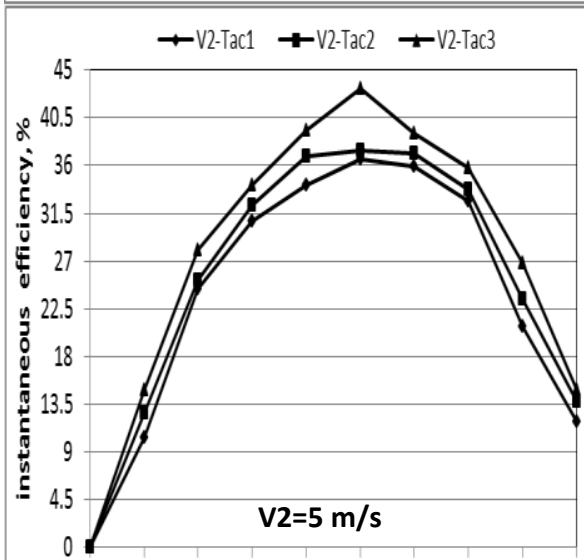

$\begin{array}{llllllllllll}\text { 8:00 } & 9: 00 & 10: 00 & 11: 00 & 12: 00 & 13: 00 & 14: 00 & 15: 00 & 16: 00 & 17: 00\end{array}$ Time of day, $h$

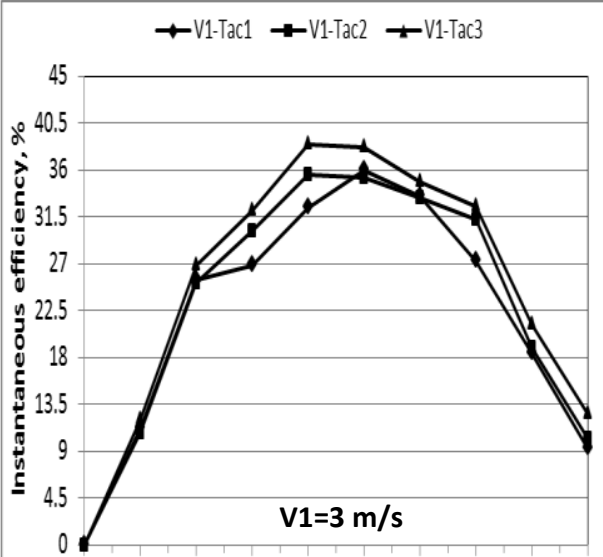

$\begin{array}{lllllllllllllll}8: 00 & 9: 00 & 10: 00 & 11: 00 & 12: 00 & 13: 00 & 14: 00 & 15: 00 & 16: 00 & 17: 00\end{array}$

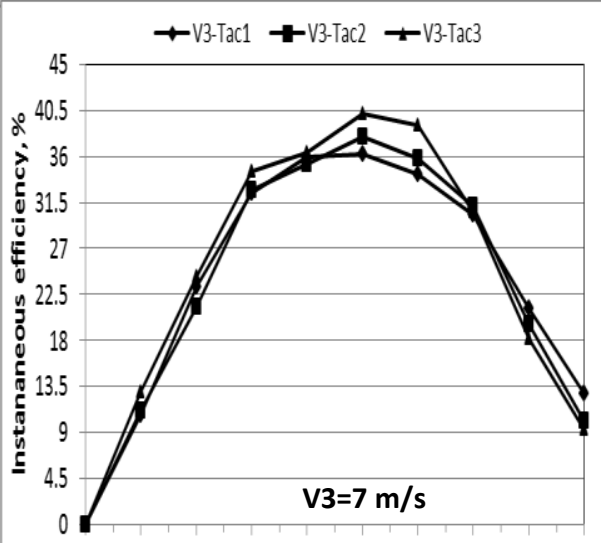

$\begin{array}{llllllllll}8: 00 & \text { 9:00 } & 10: 00 & 11: 00 & 12: 00 & 13: 00 & 14: 00 & 15: 00 & 16: 00 & 17: 00\end{array}$ Time of day, $\mathrm{h}$

Fig.(6):Effect of cooled air velocity and cooling tactic on the solar still instantaneous thermal efficiency. 
For the highest values of efficiency at noon, the increase of air velocity from $1.4 \mathrm{~m} / \mathrm{s}$ (without cooling) to $5 \mathrm{~m} / \mathrm{s}$ (cooled air) increased the instantaneous efficiency from 32.4 to $36.6,38.47$ and $43.2 \%$ at cooling tactic of $5_{\min }$ on $-10_{\min }$ off, $10_{\min }$ on $-10_{\min }$ off and $20_{\min }$ on $-10_{\min }$ off, respectively. This may be due to the increase occurred in saline waterinner glass difference without notable change for the heat stored in the water bulk. By increasing the cooled air velocity to $7 \mathrm{~m} / \mathrm{s}$, the solar still instantaneous efficiency decreased and the value become closed to the lower velocities under all cooling tactics. According to the previous discussion, the increase of cooled air velocity up to $5 \mathrm{~m} / \mathrm{s}$ raised the solar still instantaneous efficiency by about $10.80 \%$ higher than solar still without cooling, while air velocity of $7 \mathrm{~m} / \mathrm{s}$ gave a less enhancement.

\section{CONCLUSION}

In the present work, the cooling effect on the temperatures, productivity and instantaneous thermal efficiency of a conventional passive pyramid solar still was investigated by using a controlled and regulated cooled-air stream over the glass cover. The solar still was coupled to iced-cooling unit to reduce the temperature of the supplied air by the fan. According to the obtained results, the increase of air velocity from $1.4 \mathrm{~m} / \mathrm{s}$ (natural wind) to $5 \mathrm{~m} / \mathrm{s}$ (cooled air) and cooling tactic of 20minon -10min off accompanied by slight decrease in the saline water temperature followed by a remarkable increase in water-inner glass temperature difference $\left(\Delta \mathrm{T}_{\mathrm{wgi}}\right.$ ) from 10 to $21^{\circ} \mathrm{C}$ and the productivity from 0.505 to $0.645 \mathrm{~L} / \mathrm{m}^{2} . \mathrm{h}$. The highest accumulated yield of $3.545 \mathrm{~L} / \mathrm{m}^{2}$.day and instantaneous efficiency of $43.2 \%$ were achieved at air velocity of $5 \mathrm{~m} / \mathrm{s}$ and cooling tactic of $20_{\mathrm{min}}$ on $-10_{\min }$ off with an increment of about 17 and $10.8 \%$, respectively higher than the still without cooling. Also, the air velocity of $7 \mathrm{~m} / \mathrm{s}$ has irrelevant effect on the solar still performance. Ultimately, it can use the PV system in future to operate the electric motor in order to make the system more economic.

\section{REFERENCES}

Al-Garni, A.Z. (2012). Productivity enhancement of solar still using water heater and cooling fan. J. Sol. Energy Eng., 134(3):031006. 
Bhardwaj, R., M.V. ten Kortenaar and R.F. Mudde (2015). Maximized production of water by increasing area of condensation surface for solar distillation. Appl. Energy, 154: 480-490.

El-Samadony, Y.A.F. amd A.E. Kabeel (2014). Theoretical estimation of the optimum glass cover water film cooling parameters combinations of a stepped solar still. Energy, 68:744-750.

El-Sebaii, A.A.(2004). Effect of wind speed on active and passive solar stills. Energy Convs. and Manag., 45:1187-1204.

Kabeel, A.E. (2009). Performance of solar still with a concave wick evaporation surface. Energy, 34(10): 1504- 1509.

Kalidasa ,M. K., K.K. Chockalingam, K. Srithar (2008). Progresses in improving the effectiveness of the single basin passive solar still. Desalination, 220 (1-3):677-686.

Kaushal, A. (2010). Solar stills: A review. Renew. and Sustain. Energy Rev., 14(1): 446-453.

Nafey, A. S., M. Abdelkader, A. Abdelmotalip and A. A. Mabrouk (2000). Parameters affecting solar still productivity. Energy Convers. and Manag.,42:1797-1809.

Nafey, A. S., M. Abdelkader, A. Abdelmotalip and A. A. Mabrouk (2001) Solar still productivity enhancement. Energy Convs. and Manag., 42:1401-1408.

Nafey, A. S., M. Abdelkader, A. Abdelmotalip and A. A. Mabrouk (2002). Enhancement of solar still productivity using floating perforated black plate. Energy Convers. and Manag., 43(7): 937946.

Nayi, K. H. and K. V. Modi (2017). A detailed technical review on square pyramid solar still. Int. J. of Adv. Res. and Innovat. Ideas in Edu, 3(2): 3759-3766. 
Omara, Z. M., A. S. Abdullah, A. E. Kabeel and F. A. Essa (2017). The cooling techniques of the solar stills' glass covers-A review. Renew. and Sustain. Energy Rev., 78: 176-193.

Samee, M. A., U. K. Mirza, T. Majeed and N. Ahmad (2007). Design and performance of a simple single basin solar still. Renew. and Sustain. Energy Rev., 11(3): 543-549.

Somwanshi, A., and A.K. Tiwari (2014). Performance enhancement of a single basin solar still with flow of water from an air cooler on the cover. Desalination, 352: 92-102.

Srithar, K., T. Rajaseenivasan, N. Karthik, M. Periyannan and M. Gowtham (2016). Stand alone triple basin solar desalination system with cover cooling and parabolic dish concentrator. Renew. Energy, 90:157-165.

Suneesh, P.U., R. Jayaprakash, T. Arunkumar and D. Denkenberger (2014). Effect of air flow on $V$ type solar still with cotton gauze cooling. Desalination, 337:1-5.

Taamneh, Y. and M. M. Taamneh (2012). Performance of pyramidshaped solar still: Experimental study. Desalination, 291: 65-68.

Tanaka, H. and Y. Nakatake (2006). Theoretical analysis of a basin type solar still with internal and external reflectors. Desalination, 197:205-216.

Tarawneh, M.S.K. (2007). Effect of water depth on the performance evaluation of solar still. Jordon J. Mech. Ind. Eng.; 1:23-29.

Tawfik, M. A. (2012). Improving the performance of a pyramid-shaped solar still. Misr J Ag Eng., 29(4):1-15.

Tiwari, G.N. and H.N. Singh and R. Tripathi (2003). Present status of solar distillation. Sol. Energy, 75: 367-373. 
Velmurugan, V. and K. Srithar (2011). Performance analysis of solar stills based on various factors affecting the productivity-A review. Renew. and Sustain. Energy Rev., 15 (2): 1294-1304.

Wassouf, P., T. Peska, R. Singh and A. Akbarzadeh (2011). Novel and low cost designs of portable solar stills. Desalination, 276(1):294302.

\section{Zeroual, M., H. Bouguettaia, D. Bechki, S. Boughali, B. Bouchekima} and H. Mahcene (2011). Experimental investigation on a doubleslope solar still with partially cooled condenser in the region of Ouargla (Algeria). Energy Procedia, 6:736 - 42.

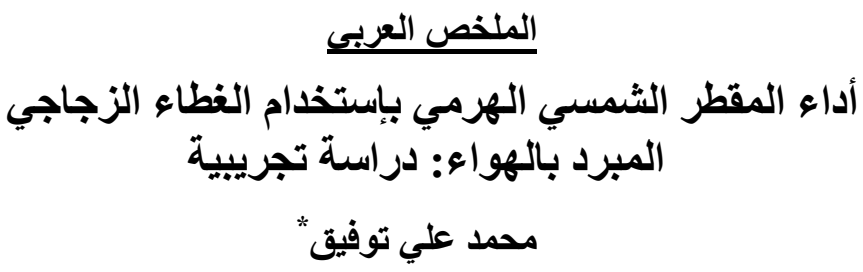

تبريد الغطاء الزجاجي يعتبر من أهم التعديلات المؤثرة علي الإنتاجية من الماء المقطر و

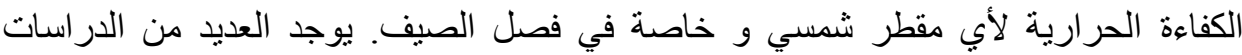
السابقة التي تتناول تبريد الغطاء الزجاجي بإستخدام الماء لتحسين أداء المقطر و لكن من المهر

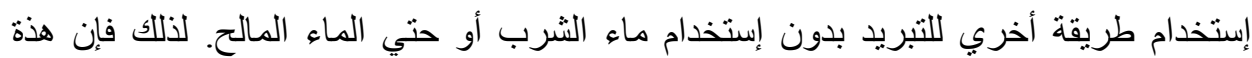

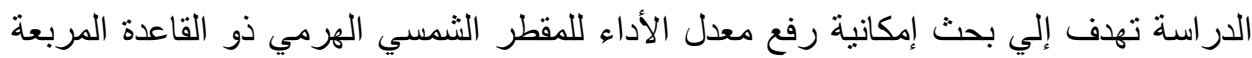

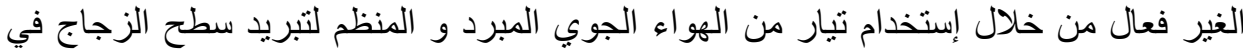

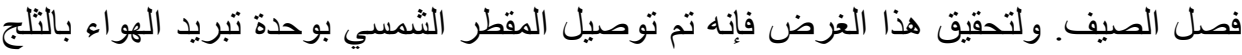

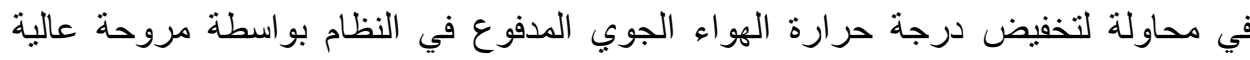

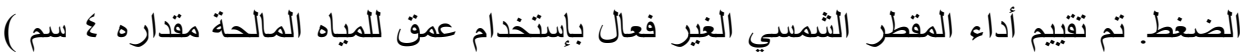
تركيز الأملاح . . 10 جزء في المليون) وذلك بدون تبريد للغطاء الزجاجي كمعاملة مرجعية ،

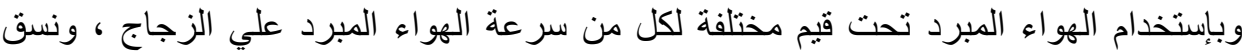

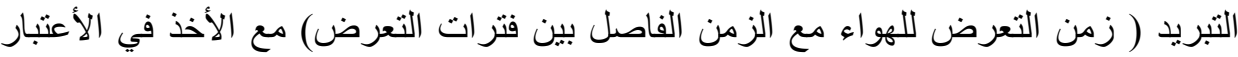

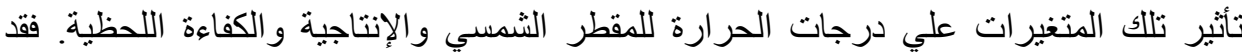

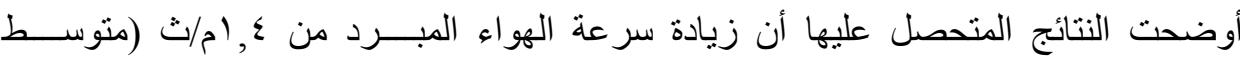

* أستاذ الهندسة الزراعية المساعد ـ كلية الزراعة ـ جامعة الزقازيق ـ مصر. 


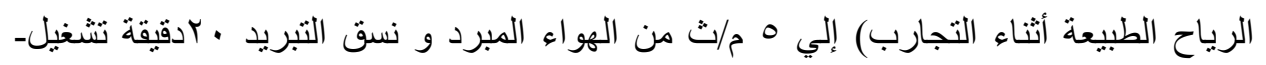

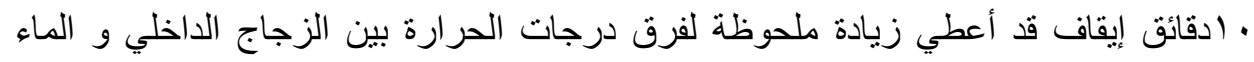

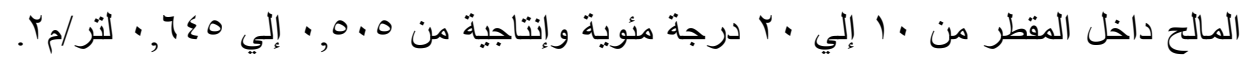

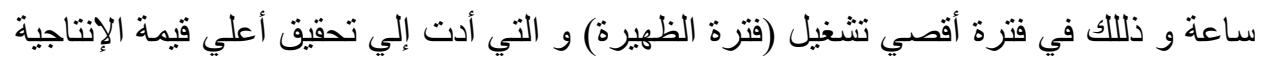

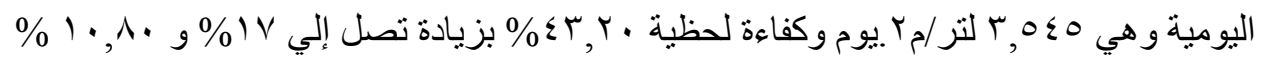

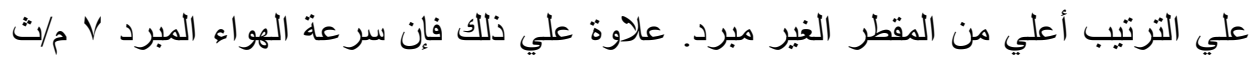

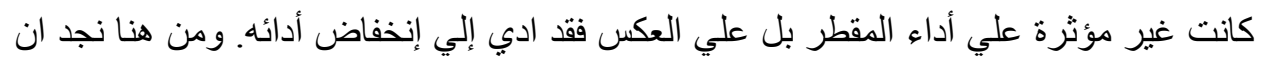

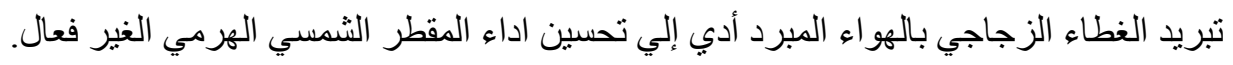

